\title{
THE ROLE OF FEDERALISM IN MALAYSIAN LOW-COST HOUSING PROVISION: THE UNEXPLORED DIMENSION
}

\author{
Andrew Ebekozien*, Abdul-Rashid Abdul-Aziz and Mastura Jaafar
}

School of Housing, Building and Planning, Universiti Sains Malaysia, Malaysia *Corresponding author: ebekoandy45@yahoo.com

Published online: 24 April 2019

To cite this article: Ebekozien, A., Abdul-Rashid Abdul-Aziz and Mastura Jaafar. 2019. The role of federalism in Malaysian low-cost housing provision: The unexplored dimension. Kajian Malaysia 37(1): 131-148. https://doi.org/10.21315/km2019.37.1.6

To link to this article: https://doi.org/10.21315/km2019.37.1.6

\begin{abstract}
Various studies have examined federalism in the context of housing provision around the globe. In Malaysia, the tension between the federal and state governments with regard to low-cost housing (LCH) is yet to be explored. This article presents part of the results of a larger research that reveals the tension between federal and state governments with regard to the provision of LCH through a qualitative approach. LCH targets set by the federal government which manifests in five-year economic plans should be met by the various states. To what extent do policy-makers consider the means with which the various states can meet these LCH targets? The states are expected to find the additional funds to deliver the LCH. Findings show there have been instances of a tussle over land and LCH provision between the federal and state governments. Other aspects of federalism which impact on LCH delivery are presented in this paper.
\end{abstract}

Keywords: federalism, government, housing provision, low-cost housing, Malaysia, qualitative research

\section{INTRODUCTION}

The word "federalism" has several possible sources that may have helped to inspire the idea: intellectual-theological, ecclesiastical, and political precedents (Riker 1964). Federalism does not have one universal definition. Boadway and Anwar $(2009,5)$ defined federalism as " a system that represents either a 'coming together' or a 'holding together' of constituent geographic units to take advantage of the 
greatness and smallness of nations." Inman (2007) affirms that the word "federal" represents any form of government that brings as one, in a coalition, constituent governments each of which recognises the legitimacy of an overarching central government to make decisions on some matters once entirely the duty of individual member states. Therefore, federalism is the separation of authority between the central government and the states that affect the safety, housing, health, education among others of each citizen living in that country. Also, federalism refers to the vertical delegation of powers to federal, state and local governments.

Watts $(2002 ; 2008)$, a foremost expert on federalism, estimated that in $2002,40 \%$ of the world's population lived in nations organised around federalism; these nations include the United States of America (USA), Argentina, Australia, Austria, Canada, Germany, India, Malaysia, Nigeria, Spain, and Switzerland. Watts (2013) reports that between 1960 and the 1980s, a number of federations were temporarily suspended or abandoned as it became clear that the federal system was not a panacea as encumbrances surfaced. Records show that about 25 functioning federations are in the world, six dismembered, and two became unitary states (Hueglin and Fenna 2015). The authors affirm that in Asia, India is one of the well-developed federalist states that are often compared with the USA and Australia. This is because India is the 7th largest country by area, second-most populous of about 1.2 billion people, and the most populous democracy in the world. India, Pakistan, and Malaysia were former British colonies; and inherited their colonial masters' influence in administration (He 2007). The intention of federalism by the former British was to hold the territories, hence failures in the era of nation-building that gave birth to India and Pakistan and the secession of Singapore from Malaysia. The concept of federalism in some countries is only on paper, practically, some of the characteristics are not there to justify the concept called federalism. This article focuses on the overview of how federalism manifests in housing delivery around selected nations with emphasis on low-cost housing (LCH) in Malaysia. This will be brought to the front burner by scholars and offer a prospect in this new area of study for further research.

\section{REVIEW OF LITERATURE}

Rodden (2010) opines that residents of the poorest localities are entitled to the same public services at the same price as residents of the wealthiest localities. This occurred over the course of the 20th century when some federations developed a political oratory. While Riker's $(1964,11)$ defined federalism as "a state in which: minimum of two levels of government rule the same land and people, each level has at least one area of action in which it is autonomous, and there is some (constitutional) guarantee of the autonomy of each government in its 
own sphere". However, this possibly leads to the central and state governments to assume the competitive role, mostly when it is an opposition state. This is the major encumbrance in federalism, which has eluded scholastic scrutiny with respect to LCH in Malaysia. Across the globe, federalism does not associate with uniform patterns of social policy because of the diversity of federal institutions and different party systems with strategies and interests. Federation was written into the 1957 Constitution in Malaysia so that the country becomes a federal system of government (He 2007; Zairil 2017). This system of government is under an elected constitutional monarchy. The Federation of Malaysia was established in the year 1963. This comprises the peninsula together with the northern quarter of Borneo but excluded the state of Brunei (Azila 2011).

In the Malaysian context, Case (2007) sees federalism as "minimalist federalism," a product of adjustment of territorial federalism to minimalist levels. A territorial federalism is a system where federalism is organised along territorial, rather than multinational lines, hence disorganises the social minorities that occasionally chafe under this rule. This implies that the government prevents regionalist sentiments from cohering in secessionist movements. This system of government is characterised by dictatorial controls and democratic procedures through which the government has efficiently maintained its duty position. Watts (2008) opines that federalism in the Malaysian context can be called "executive federalism." This is a government where a cabinet supported by majorities in their legislature tends to dominate in a parliamentary federation such as Germany, Australia, and Canada. Also, this has been a distinctive characteristic of intergovernmental relations in India, Malaysia, Austria, Belgium, and Spain (Watts 2013). Thus, it is possibly having dominance of executive in intergovernmental relations such as $\mathrm{LCH}$ matters. This article will attempt to bring this to the front burner; and allow for more scholarly contributions of the implication of federalism in LCH provision, especially in Malaysia.

\section{FEDERALISM OF SELECTED COUNTRIES AND ITS IMPACT ON HOUSING PROVISIONS}

This section reviews the USA and United Kingdom (UK) federalism's influences and its impact on housing delivery. The manifestation of the influence of federalism in housing delivery around the world cannot be overemphasised. Federalism has influenced most of the important political battles in American history, including housing provision (Robertson 2012). This is because in America, federalism's impact is so broad and so deep; therefore, giving room for political rivals to battle since the nation's founding (Robertson 2012). Housing provision is one of the social policies in America because it is a way of the government balancing the 
urban growth by promoting diversity and helping low-income households work and build wealth. Politicians have constrained the city government with the intention of protecting housing developers and property owners by making an offer to small property owners and homeowners. Tax breaks are given to owneroccupied residences to the disadvantage of the tenants. Overall, government housing policy has aided the middle and higher-income groups more than poor and minority groups. Pynoos, Schafer and Hartman (2013) report that at the national level, several biases have hindered the public housing programme. From the global perspective, one of the factors that affect the outcome of the housing programme is the inadequate representation of the minority group (low-income earners) in the decision-making process (Ebekozien, Abdul-Rashid and Mastura 2017).

In the UK, the 1990 Town and Country Planning Act and the 1991 Planning and Compensation Act allowed the bottom-up technique to policy formulation and development (Cullingworth 1999). Hence, Section 106 of the 1990 Act made it feasible for local planning authorities at development plan stage to require that a proportion of housing be affordable on a site by site basis. Implementation of this Act was partially forceful because of many factors not within the scope of this paper. Whitehead (2007) opines that the land-use planning regime in England is possibly one of the favourable used in the provision of reasonable and accessible housing. Thus, the need for greater government commitment to achieve affordable housing cannot be overstressed.

\section{MALAYSIAN LCH PROVISION}

Over the years, the Malaysian Governments have made several attempts to ensure homeownership for Malaysian citizens via various programmes and policies, especially for the medium, low-medium and low-income earners (Ebekozien, Abdul-Rashid and Mastura 2018). For the purpose of this article, the emphasis is on low-cost housing for the low-income earners. The generally accepted definition of $\mathrm{LCH}$ is a residential building that is inhabitable for the low-income earners (LIEs) in the society. Combinations of three variables are used to describe LCH in Malaysia. They are the selling price, the target household income group, and the building specifications (Ebekozien, Abdul-Rashid and Mastura 2017; AbdulRashid et al. 2018). The selling price should not exceed RM42,000; household maximum income of the LIEs should not exceed RM2,500 per month for the applicant to be qualified, and LCH size should not be less than 678 square feet (60 square metres). A LCH unit is affordable housing "Type A;" mainly developed for the low-income group in the society. This type of buildings is developed under various programmes such as Program Perumahan Rakyat (PPR), 
My First Homes Scheme, Youth Housing Scheme, MyHome, 1Malaysia Youth City Programme, and Rumah Mesra Rakyat 1Malaysia (RMR1M) (Syafiee 2016).

The provision of $\mathrm{LCH}$ has not been exempted from problems over the years even with the engagement of the private housing developers as one of the source providers from 1982 to date. From lax policy and enforcement to reluctance by banks to lend housing loan to LIEs; and inadequate institutional framework that has enhanced LCH leakages of the building life (pre-development, development, and post-development) (Ebekozien, Abdul-Rashid and Mastura 2018). This scenario among others has created issues of the demand-supply gap of LCH for many years in Malaysia. Scholars like Hasniyati and Murphy (2014), Noor Yasmin and Siti Saharah (2015), Olanrewaju et al. (2016), Alan (2017), AbdulRashid et al. (2018) among others agree inequality exist in the Malaysian LCH demand-supply. The Malaysian Government agency is not left out; Bank Negara Malaysia (BNM) Annual Report (2015) affirms that the differences in the housing stock and the number of households have widened. BNM Press Release $(2017,3)$ corroborates this submission and cites National Property Information Centre's data, that says "...30\% of new housing launches in 2015-2016 were for houses priced less than RM250,000.00 compared to 70\% during the 2008-2009 period..." This indicates that the shortage in supply of LCH in Malaysia is obvious. This shows a clear scenario of the LCH provision. The next section of this paper discusses the housing grant/loan from the federal government and tension between state and federal governments in regard to the influence of federalism on LCH provision in Malaysia.

\section{FEDERALISM IN MALAYSIAN LCH PROVISION}

The history of Malaysian federalism started during the creation of the Malay States in Peninsular Malaysia; and the resultant effect was federalism that later gave birth to Federation of Malaya (Jomo and Hui 2003). Wong (2007) postulates that the unification of Malaya with Singapore, North Borneo, and Sarawak intricate the perception that makes many to see Malaysia as a unitary state. Scholars such as Wong (2014) and Hutchinson (2014) are not comfortable with the claim that Malaysia is a central state; because the federalism is greatly centralised with a resultant effect of not only giving the central mainly the executive and legislative authority but also the main sources of income. The Ninth Schedule of the Constitution state clearly the procedure for sharing of legislative authority between the central and state governments (Zairil 2017). The State List 11 4(c) states it clearly that the State has the responsibility for the provision of housing outside the federal territories while State List 11 7(d) indicates that the federal government has the responsibility to provide loans to the state for housing provision. Also, State 
List 11(a) gives state power for land tenure, registration of titles, deeds relating to land among others. Article 83 categorically states that the federal government is entitled to acquire land in a state for federal matters. This is subject to the condition that if the land in question belongs to the state government; negotiations have to be conducted between the state and federal governments.

Penang Institute (2014) reports that state governments in the same party with the central government are treated as subordinate rather than a partner to the federal government. State governments governed by different parties are often marginalised, disfavoured against or even overthrown through the centrallyarranged defection of parliament members. The resultant effect of this is the exclusion of the state governments from the source of income and other resources. It goes beyond this; the state governments are controlled by sourcing for loan externally even with genuine reasons. The federal government has the overall authority to formulate policies on LCH. Abdul-Rashid et al. (2018) report that housing in Malaysia inclusive of LCH is woven into the complex structure of federal and state governments with inconsistencies arising from between the federal government LCH aspirations and state governments as implementers.

However, many state governments have transferred their responsibility to the central government because of inadequate resources (Abdul-Rashid et al. 2018). The resultant effect of this is that some state governments are agitating for restructuring the revenue blueprint for the betterment of all. The people of the Borneo States (Sabah and Sarawak), Terengganu, and Kelantan (oppositionrun states), as at the time of this study have started asking for higher petroleum royalties for their states (Penang Institute 2014). Past records show that the Borneo States are part of the original members of the Malaysian Federation, hence, the need for the central government to comply with the joint agreement that was signed before they joined the Federation, rather than the contrary (Lim 1997). It is obvious that the Borneo States believe that the central government is not sincere to their demands including the promise of $\mathrm{LCH}$ provision as a social welfare to them.

Azhar (2006) asserts that state governments are constrained from borrowing by the constitution but depend on the federal governments grants and loans to undertake projects. The author opines that fiscal decentralisation is possibly not the solution to the financial encumbrances of Malaysia's states. This is because of the inadequate economies of scale in some of the states and fiscal decentralisation may not be a better alternative. It is therefore suggested that the federal government should revise the state grants every five years for the provision of subsidised housing for the poor and programmes for squatter settlements. In Malaysia, the Constitution has not helped the matter by further constraining the state governments from borrowing (Zairil 2017). It is feasible that federalism in Malaysia can advance an established central government but at the state level, the assurance is not certain. Lawson (2009) asserts that for about a century, the Swiss non-profit 
housing, a non-government organisation, has been part of the urban landscape. The author opines that the Swiss Government provides finance for non-commercial housing, self-governing and stable organisations for financing non-commercial housing, although on an affordable and accessible price. The fund for this type of project comes from bonds and the state is used as the guarantee (Dowling 2016). The author avers that in Britain, new financial instruments such as social impact bonds are made available to the financially literate and economically productive to solve social encumbrances and enable cost saving in the long-run. This is another form of wealth transfer to the masses. This is a good model. Paris (2007) affirms the need for states to be well funded to provide LCH. Also, states should be the ones to supply request of LCH demand to the federal government because they are the implementers. The author suggests cooperation, consultation, sharing knowledge, setting aside politics among others as essential variables to getting the $\mathrm{LCH}$ needs right.

\section{METHODOLOGY}

In an attempt to gain insights and to understand the participants' perceptions of the "issue", whether as an individual or groups about their opinions, views, understandings, and beliefs the qualitative approach was adopted (Fellows and Liu 2015). This study adopted the phenomenological type of qualitative research. The authors aver that phenomenology attempts to develop a coherent and comprehensive view of the subject matters from the perspective of people who have experienced a phenomenon. Therefore, the aim of this research is to gather on in-depth comprehension of the individual's background, knowledge, and reasoning rather than relying on statistical analysis surveys to real-life problems. Stysko-Kunkowska (2014) opines that the phenomenology type of qualitative research design is deemed exploratory and descriptive in nature via collecting data from participants who have had the experience. This study describes the lived experiences of the impact of Federalism on LCH Provision in Malaysia as described by participants (Creswell 2014).

An in-depth semi-structured type of face-to-face oral interviews was conducted while the validation was done by secondary sources (newsprints and government documents). Semi-structured interviews are usually conducted to obtain definite and in-depth answers relevant to the particular problem (Sekaran and Bougie 2016). Epistemology, a type of philosophical paradigm was adopted because it asks into the idea of information and truth (Patton 2015). The author opines that some questions come up, such as: what is the root-supply of information? How trustworthy are these sources? What can one know? Purposive and snowball sampling, a type of qualitative sampling techniques was adopted. The purposive 
sampling allows the sample to be selected based on characteristics of a population and the objective of the study (Creswell 2014). While the snowball sampling allows the researcher to identify a very small number of the participants and, after the oral interview, requests that source to identify further sources until saturation is achieved (Fellows and Liu 2015). The research adopted a thematic analysis because it is a mechanism for identifying, analysing and reporting themes within research data (Stysko-Kunkowska 2014). The summary of the participants' description and locations is presented in Table 1. The participants were well selected to reflect a good representation of the practitioners across the spectrum and knowledgeable in the subject matter in order to achieve saturation. The names of the participants, designations, organisations, and locations were hidden for privacy in line with the agreement between the researchers and the participants. Table 1 shows that $\mathrm{S} 1$ to S8 - the participants from the state government housing department (eight), P1 to P9 - housing developers (nine), E1 to E8 - estate valuers/property consultants (eight), and NGO1 - house-buyers association (one) were the participants. The description column in regard to the state description represents the political status before the 14th Malaysian General Election, held on the 9th May 2018.

Before the commencement of the physical one-to-one oral interviews, invitation letters administered to states and federal territories across the country. The essence was to brief them the scope of the study and seek their cooperation with the pledge that the interview would be treated with the utmost confidentiality and the identity of the participants would be secluded. Only seven states and one territory indicated interest to be interviewed. This was conducted between May and November 2017 while 26 interview sessions were conducted because of the need to achieve saturation and validation of findings that emerged during the oral interviews. For the purpose of this article, the territory would be counted as a state, hence a total of eight states were covered. A semi-structured oral interview approach was adopted for data collection as earlier stated. Maunganidze (2013) considers this approach of data collection as the most suitable because it gives participants the platform to communicate themselves unreservedly without being restricted in their answers particularly regarding the elements of federalism in $\mathrm{LCH}$ provision between the state and federal governments. A pilot oral interview was conducted with five participants within the sub-sample study area before the full oral interview sessions. The oral interviews took the duration of seven months and each interview session was about 60 and 90 minutes. The general consensus for the qualitative research is that a researcher needs to demonstrate that the study is credible (Creswell 2014). The study adopted triangulation, researcher reflexivity, member checking, and collaboration as a mixed-validity approach (Creswell and Creswell 2018). 
Table 1: Summary of participant's description and locations

\begin{tabular}{|c|c|c|c|}
\hline ID & State/Territory & Description & Rank \\
\hline \multicolumn{4}{|c|}{ State Government Housing Department Staff (S) } \\
\hline S1 & State A & Eastern Malaysian state & Senior staff \\
\hline S2 & State B & State controlled by the ruling party & Management staff \\
\hline S3 & State C & State controlled by the opposition & Management staff \\
\hline S4 & State D & $\begin{array}{l}\text { The state once controlled by the } \\
\text { opposition }(2008-2013)\end{array}$ & Management staff \\
\hline S5 & State E & State controlled by the ruling party & Management staff \\
\hline S6 & State F & State controlled by the opposition & Management staff \\
\hline S7 & State G & State controlled by the opposition & Management staff \\
\hline S8 & State H & State controlled by the ruling party & Senior staff \\
\hline \multicolumn{4}{|c|}{ Housing Developers (P) } \\
\hline $\mathrm{P} 1$ & State C, E \& F & One of the top developers & Assistant manager \\
\hline $\mathrm{P} 2$ & State C & Private developer & Project manager \\
\hline P3 & State H & One of the top developers & Marketing manager \\
\hline P4 & State G & One of the top developers & Area marketing manager \\
\hline P5 & State G & Private developer & Project manager \\
\hline P6 & State F & Private developer & Director \\
\hline P7 & State C & Private developer & Director \\
\hline P8 & State D & Private developer & Director \\
\hline P9 & State H & Private developer & Engineer \\
\hline \multicolumn{4}{|c|}{ Estate Valuers/Property Consultants (E) } \\
\hline E1 & State E & Property consultant & Director \\
\hline E2 & State C & Property consultant & Principal partner \\
\hline E3 & State C \& E & Property consultant & Senior partner \\
\hline E4 & State C \& E & Property consultant & Valuation manager \\
\hline E5 & State C & Property consultant & Principal housing review \\
\hline E6 & State C & Property consultant & Director \\
\hline E7 & State C \& E & Property consultant & Senior estate planner \\
\hline E8 & State E & Property consultant & Director \\
\hline \multicolumn{4}{|c|}{ Non-Governmental Organisation (Housing Matter) (NGO) } \\
\hline NGO1 & State E \& G & House-buyers association & \\
\hline
\end{tabular}


As earlier reported, thematic analysis was used to analyse the qualitative data obtained from the physical one-to-one oral interviews. The researchers began questions on a broad note before tracking explicit questions based on the answers of the participants and guided by the prepared interview themes. The oral interview word for word transcripts was generated to ease the interpretation of the data and enable the collection of quotes for descriptive reasons (Sekaran and Bougie 2016). The finished interpretations were then checked against the scripts, and after that, adjustments were made. The research applied theme, narrative, in-vivo, and emotion coding techniques (Saldana 2015). A sum of 95 codes was determined and arranged (classifications) in view of reference, incidence, the rate of recurrence, and relationship. The study derived 18 categories from the 95 codes. From the 18 categories emerged three themes. The themes and the link are the major consequences of this investigation. It is a novel information about the idea of "qualitative approach to investigate the impact of federalism on $\mathrm{LCH}$ provision in Malaysia" from the viewpoint of the members interviewed in the investigation and gives exceptionally useful bits of knowledge into the hints of the effect of federalism on LCH provision in Malaysia. The discoveries are accounted for and examined in detail in the subsequent part.

\section{FINDINGS AND DISCUSSION}

Studies in regard to the impact of federalism on Malaysian LCH provision are few. Few previous scholars have been impassive on federalism in $\mathrm{LCH}$ provision in Malaysia, for example, Azhar (2006), Syafiee (2011), and Abdul-Rashid et al. (2018). All authors attempt to discuss the subject of Malaysian LCH federalism but were inconclusive and lacked evidence. Azhar (2006) affirms that since the federal government takes greater taxation power, state governments are left with nothing. The promises to their people, for example, a programme for squatter settlements, provision of subsidised housing for the LIEs among others are dashed. Syafiee (2011) discussed LCH provision as regard developmental state or neo-liberal policy but was impassive and lacked empirical evidence. While Abdul-Rashid et al. (2018) noted that inconsistencies arise between the federal government LCH aspirations and state governments as implementers. The existing state of affairs seemed to have intensified and increased LCH demand-supply differences in Malaysia. The discoveries and conversation will be examined under three themes:

\section{Theme One: LCH Scenario}

Theme one "LCH scenario" gives a concise view of the situation of LCH in Malaysian states. Thus, answers from the states regarding the LCH situation 
indicates high demand-supply gap as presented in Table 2. From the investigation, only "State D" indicates "not that critical." Indeed, even at that, "State D" is having at least 40,000 people on the register of $\mathrm{LCH}$. The official figures do not tell when it will reach their turn to secure a home. This study finding agrees with Bakhtyar et al. (2013), Annual Report BNM (2015), Abdullateef, Seong and Lee (2016), and Abdul-Rashid et al. (2018). The authors' findings show that the shortage of $\mathrm{LCH}$ in Malaysia is severe. Viewpoints from participants (P2, P4, P5, P6, NGO1, $\mathrm{E} 3, \mathrm{E} 5, \mathrm{E} 7$, and E8) agree with the state government housing department staffers' submission. In State G, due to "unethical waiver" granted by the state government housing department to developers, we have 35,000 units unoccupied while 17,000 units are on the waiting list. This is one of the outcomes of the relaxed state of LCH policy and enforcement in a system.

Table 2: Malaysian LCH scenario

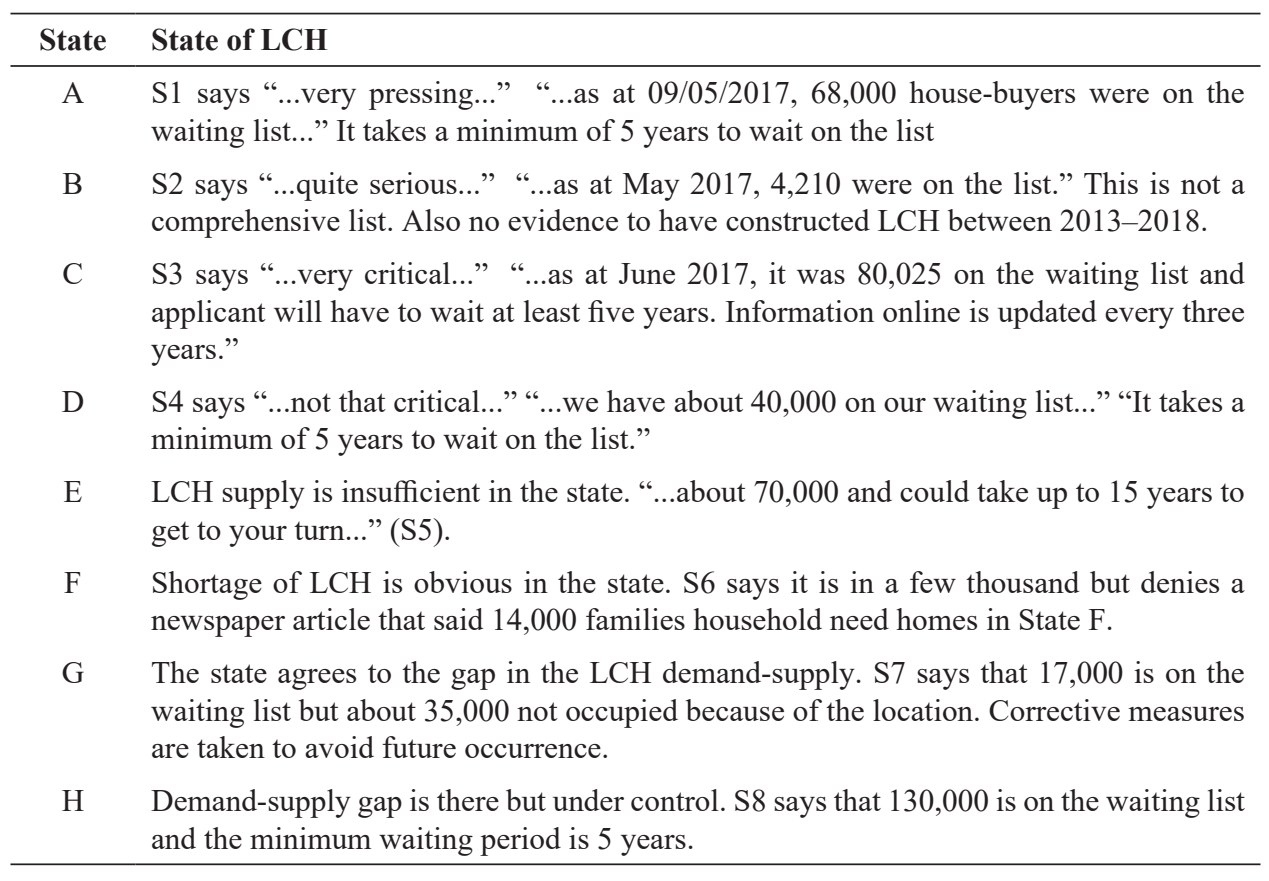

\section{Theme Two: Grant and Loan from Federal Government}

The Malaysian Constitution states that among other responsibilities, the federal government should make available housing grant and loan to states for the provision of LCH at the state level. Previous studies, for example, Azhar (2006) indicates that substantially more noteworthy tax assessment control is appointed to the central government. This has prompted monetary centralisation. Thus, the need 
for this investigation to verify this constitutional obligation cannot be ignored. S1 (State A) says "...the federal government gives limited grants for LCH through Jabatan Perumahan Negara (JPN)..." This indicates that the housing grant from the federal government is insufficient for the state governments to fulfil their promises to the people. Viewpoints from S2 (State B) aligns with S1 submission while S3 (State C) says that they do not receive a direct housing grant from the federal government. What operates in State $\mathrm{C}$ is that the state provides the land while the federal government via their agencies or private developers build their People's Housing Programme (PPR) a form of LCH. The original concept of PPR is for the federal government to build and transfer the houses to the state to collect subsidised rent and maintain the building. In the case of State $\mathrm{C}$, one of the federal agencies is the one collecting the rent. For State D, E, and H, the PPR is funded by the federal government housing grant. The federal construct and hand-over to State $\mathrm{D}, \mathrm{E}$, and $\mathrm{H}$ for rent collection and maintenance respectively. The discrepancy between State $\mathrm{C}$ and State $(\mathrm{D}, \mathrm{E}$, and $\mathrm{H})$ in this regard indicates that federalism is at play. Findings from this study indicate that the federal government is not giving all states equal treatment in regard to the grant for the LCH provision. Also, some states, especially the opposition states have been denied housing-grant because of party difference. Participants (NGO1, E4, E8, P1, P3, P6, and P8) are worried about high politics involved in the provision of housing-grant from federal to state governments. If this is not curtailed now, the prospect of agitation by unfavoured states is feasible.

\section{Theme Three: Tension between State and Federal Governments}

Theme three shows germane areas where there have been tensions between states and federal governments. Participant S1 from State A says that some time ago, the federal government agreed to release funds for the PPR project in exchange for land to the federal government, "...the state defiantly disagreed..." The resultant effect is that neighbouring states were getting grants while State A was denied house-grants for many years. The Constitutional regulation that land belongs to the State has some legal and administrative impact on current $\mathrm{LCH}$ provision in Malaysia (NGO1, E4, P4, P8, and P9). Viewpoints from participant S2 (State B) and S8 (State H) say there is a cordial and harmonious relationship between the federal government and state in terms of $\mathrm{LCH}$ provision. This should be expected because of same party alliance; hence, tension will not be pronounced. While State C says "...no single PPR for quite some time now, even the only one on the pipeline, not sure if it will be given to the state, this is as good as nothing..." In the newsprint, one of the State C Executive Member says that State $\mathrm{C}$ has been totally sidelined, underestimated and dismissed to-date, not; in any case, one unit of such federally commenced public affordable housing has been built in State C. 
This finding agrees with the Penang Institute (2014) submission that the federal government opposition states are marginalised and discriminated against. State C accuses the central government of totally neglecting to address the principal issue of property proprietorship by first home-purchasers; among the issues is the high house-credit negative response rate. Participants (P1, P2, P7, E2, E3, E4, and E7) agree with S3 submission. For State D, there was tension between the years 2008 to 2013, when it was ruled by the opposition party. During that period, there was a request to the federal government for the fund to build $\mathrm{LCH}$, the federal government turned down that request possible because of the party differences, another form of federalism in $\mathrm{LCH}$ provision. This was confirmed by the newsprint.

Participant S7 (State G) says “... a few years ago, the federal (government) acquired land for the purpose of school, after a short while, the same land was sold out to a private commercial company. The housing developers were not happy over the development..." Also, in the same state, a completed federal government $\mathrm{LCH}$ completed project took more than three years to resolve the list of eligible persons qualified for LCH because the federal and state governments in "State G" had a different list of LIEs (S7). This is because the state insists that the rule of eligibility of allocation of LCH should be strictly followed as against the insertion of non-eligible persons for political gains. S7 recommends "...the need to have an independent agency without political and top government officials' influence that will manage LCH administration..." In State F, viewpoints from participant S6 played down the allegation of tension between the federal and the state governments with regard to $\mathrm{LCH}$, although they recommended that the federal government should give housing loans to LIEs. The newsprint confirms that the federal government provides the LCH unit worth RM150,000 but the selling price was set at RM50,000 for the State F poor. The Minister from the opposition accused the state government of focusing on luxurious condominiums. The federal government intention is to woo the State F people to their party. Another germane example of federalism is the issue of Cabotage Policy that has made LCH in one of the states covered very expensive, although the federal government ceased the policy with effect from 1st June 2017. This was confirmed by the newsprint. From the study findings, it is obvious that federalism is more severe in State A, C, F, and $\mathrm{G}$ respectively. This is an indication that federalism is more negatively significant when there is an opposition between the state and federal governments.

\section{CONCLUSION}

Findings from this investigation have made new contributions with empirical proof. Before now, the paucity of studies in regard to federalism in $\mathrm{LCH}$ provision in Malaysia was obvious as shown in the reviewed literature. The literature 
needs the help of research that will uncover the nature and greatness of the difficulties experienced by states controlled by the opposition party in Malaysia in the provision of $\mathrm{LCH}$. Such research will help furnish government officials and politicians with more grounded information of how federalism impact on $\mathrm{LCH}$ provision in Malaysia, especially opposition states and how best to mitigate with respect to housing provision. In addition, researchers will have the capacity to dig out new information and regard the discoveries as a road for information-based advancement and development. Hence, this article has established that federalism manifest itself in Malaysian LCH delivery, from land issues to LCH development between state and the federal governments, and discrepancies in the provision of housing grants/loans from federal to state governments for LCH development, including maintenance. This indicates that opposition states suffered more from the federal government in regard to housing loans/grants and LCH projects. As opined by Paris (2007), states should be well funded equally to provide LCH and supply request of housing demand to the federal government because they are the implementers. The Malaysian Government should consider Lawson's (2009) suggestion as adopted by the Swiss. It is a concept where non-business housing will be part of the urban scene and encourage non-profit housing. Also, the federal government should provide sufficient designated grant and loan for housing provision via the states irrespective of the party alliance. More independent and sustainable institutions should be strengthened to provide finance for non-business housing. This should be encouraged using the state as a guarantee by pooling monetary demand to raise money by means of bonds. Cooperation, consultation, sharing knowledge, setting aside politics, are all essential ingredients to getting the LCH needs right. Hence, the way out of the negative impact of federalism on LCH provision in Malaysia is "cooperative federalism" and not "dual federalism."

\section{ACKNOWLEDGEMENTS}

This work was supported by the Universiti Sains Malaysia [1001/PPBGN/816296].

\section{REFERENCES}

Abdullateef O, Y. Seong and L. Lee. 2016. Rethinking affordable housing delivery: An analytical insight. MATEC Web of Conferences 47(2016). https://doi.org/10.1051/ matecconf $/ 20164704002$

Abdul Rashid Abdul-Aziz, M.H.J. Tah, O. Abdullateef and Ahmed Umar Abdullahi. 2018. The nexus between government and private developers in Malaysia housing sector. In Country of age: Trends and issues in housing in Asia cities, eds. U. Sengupta and A. Shaw, 110-136. London, United Kingdom: Routledge. 
Alan, T. 2017. Move forward with affordable housing. The Star Online. 14 October. https://www.thestar.com.my/business-news/2017/10/14/move (accessed 15 October 2017).

Azhar Saiful Rosly. 2006. Fiscal federalism in Malaysia: Challenges and prospects. Dialogues on the practice of federalism. http://www.forumfed.org/library/fiscalfederalism-in-malaysia-challenges-and-prospects/ (accessed 10 October 2017).

Azila Ahmad Sarkawi. 2011. Planning legislation in a view of "federalism" in Malaysia. In Readings in Malaysian urban and regional planning, eds. Mariana Mohamed Osman, Mansor Ibrahim and Syahriah Bachok, 8-15. Selangor, Malaysia: International Islamic University Malaysia Press.

Bakhtyar Bakar, Zaharim Azami, Sopian Kamaruzzaman and Moghimi Saeid. 2013. Housing for the poor people: A review on low-cost housing process in Malaysia. Environment and Development 9(2): 126-136.

Bank Negara Malaysia. 2017. Access to financing is not the primary issue for affordable housing (press release). 18 July. Putrajaya, Malaysia: Bank Negara Malaysia.

2015. Bank Negara Malaysia annual report, 2014. Putrajaya, Malaysia: Bank Negara Malaysia.

Boadway, R. and Anwar Shah. 2009. Fiscal federalism: principles and practices of multiorder governance. New York, USA: Cambridge University.

Case, W. 2007. Semi-democracy and minimalist federalism in Malaysia. In Federalism in Asia, eds. B. He, B. Galligam, and T. Inoguchi, 124-143. Cheltenham, United Kingdom: Edward Elgar.

Creswell, J.W. 2014. Research design. Qualitative, quantitative, and mixed methods approaches. 4th ed. Thousand Oaks, California, USA: Sage.

Creswell, J.W. and J.D. Creswell. 2018. Research design: Qualitative, quantitative, and mixed methods approaches. 5th ed. London, United Kingdom: Sage.

Cullingworth, B. 1999. British planning: Fifty years of the urban and regional policy. London, United Kingdom: Athlone.

Dowling, E. 2016. In the wake of austerity: Social impact bonds and the financialisation of the welfare state in Britain. New Political Economy 22(3): 294-310. https://doi.or g/10.1080/13563467.2017.1232709

Economic Planning Unit. 1991. Sixth Malaysia Plan. Kuala Lumpur, Malaysia: Government Printing Office.

Ebekozien, A., Abdul-Rashid Abdul-Aziz and Mastura Jaafar. 2018. Low-cost housing leakages in Malaysia: The unexplored dimension. Pacific Rim Property Research Journal 24(3): 249-264. https://doi.10.1080/14445921.2018.1552471

2017. Comparative analysis of low-cost housing policies in Malaysia and Nigeria. International Transaction Journal of Engineering, Management, \& Applied Sciences \& Technologies 8(3): 139-152.

Evans, A.W. 1985. Urban economic: An introduction. Oxford, United Kingdom: Basil \& Blackwell.

Federal Government of Nigeria. 2006. National housing policy. Abuja, Nigeria: Federal Ministry of Works, Housing, and Urban Development.

Fellows, F.R. and A.M.M. Liu. 2015. Research methods for construction. 4th ed. West Sussex, United Kingdom: Wiley-Blackwell. 
FMT News. 2017. Penang: We've built four times more affordable houses than BV. 6 February. $\quad$ https:/www.freemalaysiatoday.com/category/nation/2017/02/06/ penang-weve-built-four-times-more-affordable-houses-than-bn/ (accessed 10 October 2017).

Goh, S.T. 2013. The views of the house-buying public. In Housing the nation, policies, issues, and prospects, ed. O.S. Kuang, 127-136. Kuala Lumpur, Malaysia: Cagamas.

Hasniyati Hamzah and L. Murphy. 2014. The role of institutions in sustaining mandatory LCH. Pacific Rim Property Research Journal 20(2): 129-144. http://doi: 10.1080/14445921.2014.11104391

He, B. 2007. Democratisation and federalisation in Asia. In Federalism in Asia, eds. B. He, B. Galligan and T. Inoguchi, 1-32. Cheltenham, Great Britain: Edward Elgar.

Hueglin, O.T. and A. Fenna. 2015. Comparative federalism: A systematic inquiry. 2nd ed. Toronto, USA: University of Toronto Press.

Hutchinson, F. 2014. Revisiting Malaysia's centralised Federation. Federalism in Malaysia: Design and practice conference. Proceedings of the Penang Institute, Traders Hotel, Pulau Pinang. 15-16 September.

Inman, P.R. 2007. Federalism's value and the value of federalism. CESifo Economic Studies 53(4): 522-560.

Inman, P.R. and L.D. Rubinfeld. 1997. Rethinking federalism. The Journal of Economic Perspectives 11(4): 43-64.

Jomo, K.S. and W.C. Hui. 2003. The political economy of Malaysian federalism: Economic development, public policy, and conflict containment. Journal of International Development 15: 441-456.

Lawson, J. 2009. The transformation of social housing provision in Switzerland mediated by federalism, direct democracy, and the urban/rural divide. International Journal of Housing Policy 9(1): 45-67.

Lim, H.H. 1997. Sabah and Sarawak in Malaysia: The real bargain or what have they gotten themselves into? In Sabah and Sarawak: The politics of development and federalism, ed. F.K.W. Loh, 236-239. Pulau Pinang, Malaysia: Penerbit Universiti Sains Malaysia.

Maunganidze, F. 2013. The role of government in the establishment and development of SMEs in Zimbabwe: Virtues and vices. Journal of Business Administration and Education 4(1): 1-16.

Ministry of Urban Wellbeing, Housing and Local Government. 2013. The national housing policy. In Housing the nation: Policies, issues, and prospects, ed. O.S. Kuang, 107-116. Kuala Lumpur, Malaysia: Cagamas.

Noor Yasmin Zainun and Siti Saharah Ismail. 2015. Low-cost housing demand factors in Malaysia. Applied Mechanics and Materials 773-774: 1037-1041. https://doi:10.4028/www.scientific.net/AMM.773-774.1037

Olanrewaju, A., Abdul-Rashid Abdul-Aziz, Y.S. Tan, L.L. Tat and N. Mine. 2016. Market analysis of housing shortages in Malaysia. Procedia Engineering 164: 315-322. https://doi:10.1016/j.proeng.2016.11.625

Paris, C. 2007. International perspectives on planning and affordable housing. Housing Studies 22(1): 1-9. 
Patton, M.Q. 2015. Qualitative evaluation and research methods. Thousand Oaks, CA: Sage.

Penang Institute. 2014. Federalism in Malaysia: Design and practice. Proceedings of the Penang Institute, Traders Hotel, Pulau Pinang. 15-16 September.

Pynoos, J., R. Schafer and C.W. Hartman. 2013. Housing urban America. 2nd ed. New Brunswick, USA: Aldine Transaction.

Robertson, B.D. 2012. Federalism and the making of America. New York, USA: Routledge. Riker, W. 1964. Federalism: Origin, operation, significance. Boston, USA: Little Brown. Rodden, J. 2010. Federalism and inter-regional redistribution. In The political economy of inter-regional fiscal flows: Measurement, determinants and effects on country stability, eds. N. Bosch, M. Espasa and A.S. Olle, 191-219. Cheltenham, United Kingdom: Edward Elgar Publishing Limited.

Saldana, J. 2015. The coding manual for qualitative researchers. 3rd ed. London, United Kingdom: Sage.

Sarawak Ministry of Housing and Urbanisation. 2017. Ministry of Housing and Urbanisation. Sarawak, Malaysia: Government Printing Office.

Sario, R. 2017. Cabotage policy for Sabah, Sarawak, and Labuan abolished from $1^{\text {st }}$ June. The Star Online. 7 May. https://www.thestar.com.my/news/nation/2017/05/07/ pm-cabotage-policy-in-sabah-scrapped/ (accessed 10 October 2017).

Sekaran, U. and R. Bougie. 2016. Research methods for business: A skill-building approach. 7th ed. West Sussex, United Kingdom: John Wiley \& Sons.

Siracusa, M.J. 2012. Encyclopedia of the Kennedys: The people and events that shaped America. Oxford, England: ABC-CLIO.

Stysko-Kunkowska, M. 2014. Interviews as a qualitative research method in management and economics sciences. Warsaw, Poland: Warsaw School of Economics.

Syafiee Shuid. 2016. The housing provision system in Malaysia. Habitat International 54(3): 210-223. https://doi: 10.1016/j.habitatint.2015.11.021 2011. Developmental state or neo-liberal policy? Housing provision in Malaysia at the crossroad. In Readings in Malaysian urban and regional planning, eds. Mariana Mohamed Osman, Mansor Ibrahim and Syahriah Bachok, 39-48. Selangor, Malaysia: International Islamic University Malaysia Press.

Watts, L.R. 2013. Typologies of federalism. In Routledge handbook of regionalism and federalism, eds. J. Loughlin, J. Kincaid and W. Swenden, 19-33. New York, USA: Routledge.

2008. Comparing federal systems. 3rd ed. Ontario, Canada: McGill-Queen's University.

2002. The relevance today of the federal idea. Proceedings of the International Conference on Federalism, Geneva, Switzerland. 20 April.

Whitehead, E.M.C. 2007. Planning policies and affordable housing: England as a successful case study. Housing Studies, 22(1): 25-44.

Wong, C.H. 2014. Revisiting Malaysia's centralised Federation. With the theme: Federalism in Malaysia: Design and practice. Proceedings of the Penang Institute. Held in Penang, 15-16 September. 
2007. Weakened federalism in the new federation. The Malaysian Bar. http://www.malaysianbar.org.my/echoes_of_the_past/weakened_federalism_in_ the_new_federation.html (accessed 10 October 2017).

Yam, M. 2013. Challenges and changes in the industry. In Housing the nation, policies, issues, and prospects, ed. O.S. Kuang, 79-89. Kuala Lumpur, Malaysia: Cagamas.

Zairil Khir Johari. 2017. The story of Malaysia through its constitution. New Mandala. https:/www.newmandala.org/story-malaysia-constitution/ (accessed 10 October 2017).

Zakki Ahmad Yahya. 1997. The government viewpoint. In Housing the nation: A definitive study, ed. C.L. See, 229-250. Kuala Lumpur, Malaysia: Cagamas. 